\title{
Luiz Rau creek and the city of Novo Hamburgo, Rio Grande do Sul
}

\author{
C. Schemes ${ }^{a *}$, D. Castilhos-Araujo and M. Lima-Magalhães ${ }^{a}$ \\ ${ }^{\mathrm{a}}$ Graduate Program in Cultural Processes and Manifestations, Universidade Feevale, \\ RS 239, 2755, CEP 93352-000, Novo Hamburgo, RS, Brazil \\ *e-mail: claudias@feevale.br
}

Received: January 17, 2015 - Accepted: May 20, 2015 - Distributed: November 30, 2015

(With 2 figures)

\begin{abstract}
This article presents a reflection on the past and current history, uses, and significance of the Luiz Rau creek to the municipality of Novo Hamburgo, Rio Grande do Sul. Its waters have always been important to the region, quenching the thirst of the local population and their livestock and providing venues for shared social interactions, but also as a destination for municipal industrial and household waste, which has polluted the waters of the creek. Our primary objective is to present and discuss these aspects with the purpose of elucidating the historical importance of this watercourse to the city of Novo Hamburgo. Toward that end, we conducted an exploratory survey to obtain the necessary inputs for such a discussion. We also employed texts from the now-defunct Jornal 5 de Abril and from Jornal NH, the highest-circulating newspaper in the region, to illustrate some situations experienced by the community. We found that municipal waste continues to be dumped into the creek, which has made it rather unloved by the local residents, but it remains firmly present in their daily lives.
\end{abstract}

Keywords: Luiz Rau creek, Novo Hamburgo, pollution, sociability.

\section{O arroio Luiz Rau e a cidade de Novo Hamburgo/RS}

\section{Resumo}

Este artigo apresenta uma reflexão a respeito da história, dos usos e dos significados que o Arroio Luiz Rau teve/tem para o município de Novo Hamburgo. Suas águas, desde sempre tiveram grande importância para a região, pois serviram para suprir a sede dos moradores e seus animais, assim como para dividir espaços de sociabilidade, mas também para a liberação dos resíduos industriais e domésticos, oriundos do município, gerando poluição em suas águas. O objetivo principal, então, é apresentar esses aspectos, discuti-los, com o propósito de elucidar a importância histórica desse curso d'água para a cidade de Novo Hamburgo. Para a realização desse propósito, elaboramos uma pesquisa exploratória, a fim de termos subsídios suficientes para essa discussão. Além disso, utilizamos textos jornalísticos, do extinto, Jornal 5 de Abril e do Jornal NH, que tem a maior circulação na região, para ilustrarmos algumas situações vividas pela comunidade. O que observamos, atualmente, é que o arroio continua recebendo dejetos da cidade, tornando-se um espaço pouco querido pelos habitantes, mas ainda muito presente no cotidiano de seus moradores.

Palavras-chave: Arroio Luiz Rau, Novo Hamburgo, poluição, sociabilidade.

\section{Introduction}

This article seeks to describe the relevance of the Vicente Luiz Rau creek to the city of Novo Hamburgo, Rio Grande do Sul, and how this relationship developed over time. The creek has witnessed advances and conflicts that occurred in the area as the result of an urban growth process tied to the idea of order and progress enshrined in the city's social imaginary. Throughout its history, it has had a close relationship with the local inhabitants, as its banks and vegetation promoted interactions and socialization among the population.

With the progress of industry in the municipality, however, this closeness ultimately became a distant memory, particularly due to pollution from industrial and domestic waste.

The Luiz Rau creek is part of the Sinos River drainage basin (Bacia Hidrográfica do Rio dos Sinos), which spans part or all of 32 municipalities. The Sinos River, the main watercourse of this basin, runs $190 \mathrm{~km}$ from its source in the municipality of Caraá to its mouth in the Jacuí Delta, in the municipality of Canoas (Baum, 2013).

First, we will provide an overview of the history of Novo Hamburgo, from its inception as a district of the town of São Leopoldo to the local population's wish for municipal emancipation. Notably, one of the driving 
forces behind this wish was the construction of a bridge over the Luiz Rau creek.

Another aspect we will address is the role of the creek as a social boundary: on one side, a city undergoing rapid urban development; on the other, a markedly disadvantaged community, with segregation of social classes and ethnicities.

Finally, we will reflect on the uses of the creek and their consequences, such as pollution, which is now one of the major issues faced by the Novo Hamburgo community.

\section{The Luiz Rau Creek and the Municipal Emancipation of Novo Hamburgo}

Novo Hamburgo, one of the constituent cities of the Sinos River Valley (Vale do Rio dos Sinos), is located on the BR-116 highway, $40 \mathrm{~km}$ from the state capital of Porto Alegre. In the $19^{\text {th }}$ and early $20^{\text {th }}$ centuries, Novo Hamburgo belonged to the municipality of São Leopoldo, one of the cradles of German immigration in Brazil. The first immigrants came to the area in 1824, landing at the former Royal Hemp Factory (Real Feitoria do Linho Cânhamo), which would later become the Colony of São Leopoldo and, ultimately, the homonymous city. Novo Hamburgo began as the Fourth District of this municipality, as made official by act of law in 1857 . The district's first colonists settled in what is not the neighborhood of Hamburgo Velho, which became a site of thriving trade and was chosen to receive the coming immigrants.

The history of the Sinos River Valley region stresses the "saga of German immigration". The official narratives place emphasis on German immigrants and their descendants as the historical agents of development and progress in the region, in a discourse generally clad in the fabric of economic development. According to Weber (2006, p. 121), the

[...] representations constructed about Novo Hamburgo, by highlighting local economic progress, is not grounded [...] on past historical situations, but rather by development and by forecasts for the future.

In the early $20^{\text {th }}$ century, the town economy revolved around leatherworking and shoe manufacturing; tanneries, saddlers, and footwear factories were established in the area, and progress in the district was radically accelerated by this incipient industrialization.

In 1924, individuals with connections in the local commerce and industry set up a group to fight for the town's municipal emancipation. This movement was the watershed moment of a new era for the town, which, in a changing scenario, gradually took on a more urban appearance, modifying the aesthetics and spatial arrangements of the old district (Selbach, 2006; Schemes, 2006; Behrend, 2002).

In the 1920s, the district underwent significant changes in infrastructure, particularly with respect to urban planning, as the only way to achieve progress. To become modern, however, the town had to overcome the past and undergo complete remodeling of its spaces. It bears stressing that human progress was considered synonymous with material progress; thus, the town
[...] sought to grow and take on the trappings of a small metropolis. To do so, it had to tear down the bridges that connected it to the past [...]. [It] renounced its colonial origins to dive headfirst into an urban dream. (Selbach, 2006, p. 115).

There is a longstanding rivalry between São Leopoldo and the village of Hamburger Berg. Precisely how and when it began is unknown, but one may deduce that the economic development of the latter gave hope to local political groups and entrepreneurs, who soon glimpsed the possibility of running the town - and managing its resources - autonomously.

Gertz (2002), in an analysis of the Deutsche Post newspaper, claims this rivalry is clearly present when, in 1924, debate began as to the erection of a monument commemorating the $100^{\text {th }}$ anniversary of German immigration, with São Leopoldo and Novo Hamburgo each wishing to host the monument. Fundraising efforts for the monument were led by two parallel committees, which would ultimately join forces when it was decided that two monuments would be constructed, one in each town. São Leopoldo would host the monument commemorating the arrival of the colonists, whereas Hamburger Berg would have one celebrating German settlement proper.

However, the municipal emancipation movement had been under consideration at least since the early years of the Republic. In 1897, a request for the disannexation of the district and the establishment of a new municipality, which would be bordered on the south by the Sinos River, was filed with the São Leopoldo town council. The request was denied, but it provides evidence of a desire for political emancipation.

One of the factors that triggered the district's struggle for municipal emancipation was the refusal by the São Leopoldo town government to pay for part of the construction of the first bridge over the Luiz Rau creek, in 1920. This bridge was important, as it represented a way to improve circulation and town business (Petry, 1944).

Leopoldo Petry, in an article published in $\mathrm{O} 5 \mathrm{de}$ Abril titled "A emancipação de Novo Hamburgo" ("The Emancipation of Novo Hamburgo"), notes that

[...] The plan to create a municipality with Novo Hamburgo as its seat $[\ldots]$ was quite old. It was born shortly following the end of the Revolution of 1893. It was, however, cast aside, $[\ldots]$ but did not die altogether. It has always remained alive in the hearts of many good people.

May 1924. While having a round of chimarrão at the office of Mr. Pedro Alles, I spoke to that citizen about his idea of taking certain steps to ascertain whether Novo Hamburgo might be split from S. Leopoldo, for, as a mere district, there were no prospects for further development of the resources of its industrial might, combined with its privileged location as a center towards which converges the trade of a large and prosperous agricultural zone, which forms its hinterland. 
Mr. Alles embraced my thoughts enthusiastically, and but two days later, we sought out Dr. Jacob Kroeff Netto, then a state legislator, to whom we made our project known. After some hesitation, he agreed. We then exposed our plans to town councilman Mr. Pedro Adams Filho, who immediately volunteered to follow us in the steps we were about to take [...] (Jornal O 5 de Abril, 1932, p. 3).

Despite the efforts of São Leopoldo politicians to hinder municipal emancipation, on 5 April 1927, Decree no. 3,818, signed by state governor Borges de Medeiros, granted Novo Hamburgo its independence.

On 20 May 1927, just over 1 month after emancipation, O 5 de Abril confirmed the importance of the bridge over the Luiz Rau creek:

Thus, we shall have a complete enlargement of Rua $1^{\circ}$ de Março and prolongation of Rua 7 de Setembro, which, leading out of this village until it reaches the São Leopoldo road, shall shorten the aforementioned street and by-pass two railroad crossings. Other improvements, which should now also be made known to all, shall be introduced on Rua 13 de Maio, where a sturdy bridge shall be constructed over the creek that crosses it. (Jornal O 5 de Abril, 1927, p. 4).

The bridge over the creek represented the possibility of development for a town that already showed clear signs of thriving industrial growth. Novo Hamburgo needed the infrastructure to further leverage these economic activities, which were essential for its political independence, and the bridge was one such essential public work.

In addition to playing a protagonist role in the movement for municipal emancipation, the creek was also a much-loved leisure venue for the population. In the 1920s and 1930s, the Luiz Rau creek was the town resort and one of its entertainment areas.

According to Selbach (2006), families would often picnic and go bird-hunting along the shaded, peaceful, tree-lined banks of the clear creek.

\section{Between Main Street and Skid Row: The Creek as Border}

After municipal emancipation and with the dawn of the 1930s, Novo Hamburgo began its urbanization process, guided by industrial growth and built upon the idea of progress and modernity, thus promoting a restructuring of its spatiality.

Luiz Rau creek - initially known as the Weinz creek - stood as chaperone and witness to these changes, serving not only as an outflow tract for municipal waters but also as an "observer" of the redesign of this German-Brazilian town and its "progress", as well as of the controversies regarding preservation and destruction that arose during the journey of advances and changes that took place within the town. The creek, in its material form, established a historical relationship with the town.

By crossing the municipality of Novo Hamburgo, the creek served as a dividing border between its inhabitants, as it intensified differences by separating the town center from its outlying areas. In the local imaginary, the creek thus became a dividing line between the ever-progressing center of town and the outlying area inhabited by its outcasts.
Until the 1940s, the town was split demographically by the creek - one side of its banks housed the elite, the inhabitants of German descent who lived predominantly in Hamburgo Velho (the oldest part of town), and the town center, largely composed of rapidly expanding commercial establishments (Selbach, 1999). Across the creek lived the "others", divided between two peripheral areas known as África and Mistura.

Amid a changing landscape, the creek had thus also become a border of sorts, separating the outskirts from the town center. The outlying area then known as Mistura (literally mix), now the Rio Branco neighborhood, was thus known because it "mixed" poorer whites and black residents. It was also the site of Rua da Limpeza, now Rua Oswaldo Cruz, where the waste of the growing town was dumped.

The living conditions of the outskirts of town, and particularly of Rua da Limpeza, did not go unnoticed by the local newspaper:

The presence of fetid, abject furrows, into which is cast the night-soil collected from cesspits across all quadrants of town, amid the houses of that otherwise promising zone constitutes a hindrance to its development, as, on the muggiest days, their noisome vapors spread unbearably and deleteriously across vast stretches [...] (Jornal O 5 de Abril, 1951, p. 5).

The area was long denied the benefits of urbanization, as recorded in this feature story:

Residents of Rua Marcílio Dias and of the Rio Branco neighborhood pray we draw the attention of the competent authorities to the intolerable stench emanating from the Weinz creek [...] It is imperative that the necessary measures be taken to address this evil, which, as well as being a great nuisance to the residents of that popular neighborhood, poses a serious threat to the health of the population. (Jornal O 5 de Abril, 1931, p. 3).

Alongside Mistura in the peripheral cartography of Novo Hamburgo and equally separated from the town center by the Luiz Rau creek was the África neighborhood (now known as Guarani), where the black population lived. The outskirts of town also "welcomed" poor white residents. Just as the Mistura area, this neighborhood was excluded from the urbanization process approximately until the mid-1950s. The living conditions of its residents were accordingly precarious (Magalhães, 2010).

The residents of these areas were mostly laborers from other towns who sought employment opportunities at the shoe factories and tanneries of Novo Hamburgo. The migration of residents from other locales across the state of Rio Grande do Sul peaked in the 1950s and 1960s, reflecting the advancing industrialization of the town.

In 1955, author Ercílio Rosa made note of the town's growth and transformations:

The town grows day by day, driven by the natural dissatisfaction of its residents. Buildings of every kind rise daily, training water courses and hewing cliff sides, in a mad rush to fill empty spaces, Novo Hamburgo spreads contentedly under the mighty wings of fruitful labor; on every corner, on every stretch of street, a machine at work: 
a little factory rises up out of nowhere [...] Unbeknownst to us, the town expands, rolling over hills and valleys [...]. The town grows day by day, transforming landscapes under its progressive fury, invading its surroundings, rutting the soil and raising houses. (Jornal O 5 de Abril, 1955, p. 3).

The creek also took on new roles as new urban forms and functions took shape in Novo Hamburgo, and gradually lost its function as a meeting place and driver of social interactions among the town residents. The growing pace of local industrialization and the new urban functions changed the lifestyle of the population, as part of a larger process, and the creek's interaction with the town residents was left behind.

\section{Luiz Rau: from Leisure to Pollution}

In the span of approximately 30 years, the town's place of leisure and point of pride became unfriendly to families and improper as an entertainment venue. On this matter, the local newspaper opined as follows:

Two faces of a town. This is our town: the Novo Hamburgo town center is admirable for its cleanliness and tastefulness of its squares; the kiosk is a true landmark, as it is not only excellently organized but also placed within the most beautiful garden of towering, flowering trees; there, one feels as if it were springtime year-round; it is the finest square I have come upon in the South; the lighting is a wonder to behold, there are no words to describe it when one reaches the highest part of town. The second face of Novo Hamburgo: the Luiz Rau creek is the greatest blight on this town, as it is not only overrun with grass, but also fouls the air throughout its course; many unpaved, uncurbed plots ruin a town; unswept streets, grass overrunning road and curb alike; sidewalks are lacking at points on the edge of the town center. (Jornal NH, 1965, p. 10).

At the time, the Luiz Rau creek was already regarded as a "blight on the town": a dirty, unseemly, contaminated place.

The creek, as mentioned above, was far from the town center, delimiting the relatively developed central business district and the outskirts. Since the earliest stages of municipal economic development, the creek had been contaminated by the waste of the surrounding tanneries, which dumped pollutants directly into its waters. The situation was so common that some newspaper stories of the time mentioned the overpowering odor of the stream:

[...] Tanneries are to be had by the dozen in our municipality. And it is precisely from these establishments, or rather, from most of these establishments, that a horrible stench, resulting from their detritus, exudes. These wastes are then dumped into the Weinz creek that runs through the whole town, fouling its waters, which give off an unbreathable vapor, particularly in proximity to its course. This fact is unquestionably the greatest contributor to the appalling local health conditions. Summer is soon upon us, and it is precisely in the warmest days that the stench is worst. (Jornal O 5 de Abril, 1931b, p. 3).
As early as 1931, the water quality of the creek was a source of concern, as it was visibly compromised by pollution from household waste and industrial waste from the local tanneries.

[...] Under the headline "Still complaining", we long ago published a complaint against facilities of a certain caliber, which pour their wastewater into the gutters. Whosoever enters Rua da República from 15 de Novembro will have his olfactory senses assaulted by a stench, given off from the gutter, that overpowers the whole block. Now, as is known to one and all, this street is the busiest thoroughfare in our urbs. (Jornal O 5 de Abril, 1931b, p. 3).

The once-clear creek now had its waters darkened by household waste and by traces of industrial pollutants. This new situation earned it the moniker Arroio Preto, or "Black Creek". Pollution of the creek continued to grow over the years, which became particularly evident during the 1960s and 1970s, which were characterized by local industrial growth and by the town's ties with the national export economy.

From the 1960s, the town grew into a city and its outskirts became populous neighborhoods, which led to a host of new issues, such as their proximity to the Sinos River and the struggle with flooding, particularly in the rainy local winters. Progress was being made, but carried with it the burden of accelerated urban growth, which predominantly penalized the residents of peripheral areas, as the advances and benefits of urbanization took much longer to reach them. In the 1960s, the Vicente Luiz Rau creek remained a municipal landmark, but carried new scars that ran deeper as urbanization and rapid industrialization progressed, shaping a "new city" in which children continued to play in the creek, but now in foul, polluted waters.

As industrialization progressed, Novo Hamburgo became known as the Footwear Capital of Brazil, and by the 1970s, the city was a small metropolis, undergoing vertical growth; historical buildings gradually became concealed, and the streets of the former town center became too narrow for the new cars purchased by local industrialists (Selbach, 1999). Consequently, the new aspirations of a "metropolis" entailed spatial reorganization and changes to the landscape; industrial progress brought benefits, but also consequences, as shown by the pollution of the creek.

With the local authorities and population uninterested in environmental issues, the vegetation that lined the banks of the creek was gradually removed, which "put an end to the picnics and bird hunts with slingshots and pellet guns" (Jornal NH, 1981, p. 15) of yesteryear.

The transformations effected in the creek were evident by the $1990 \mathrm{~s}$. The degree of pollution was such that it became a municipal landmark in itself:

Novo Hamburgo has a colorful creek. Its waters are green one day, purple the next, then black, sometimes blue. That's industrial waste being dumped. (Jornal NH, 1992, p. 18). 
According to Baum (2013), the Luiz Rau creek is located in the low point of the drainage basin - where there is essentially no slope, as reflected by slow water outflow - in the municipality of Novo Hamburgo, and flows into the Sinos River. The creek crosses the city center, carrying all untreated municipal household waste and industrial effluents to its mouth at the Sinos River. This qualitative degradation of the waters of Luiz Rau creek has occurred since the very start of anthropogenic activity in the area.

The adoption of control and enforcement measures against waste sources, particularly in the private sector (i.e., the industry), has led to a reduction in industrial pollution of the creek. Its pollution issues are now predominantly associated with untreated household waste. This lack of household wastewater treatment of house has significantly degraded the creek, compromising the natural landscape and biota of this waterway. This reality applies to the entire Sinos River basin, the creeks, streams, and rivers of which are veritable dumping grounds for untreated household waste, due to the low rate of treatment of these effluents by public utilities (Baum, 2013).

The Vicente Luiz Rau creek remains a landmark of its German-Brazilian municipality to this day. However, it is accused of becoming a blight on the city center, particularly in the wet season, when rain causes the old creek to overflow its banks and flood the surrounding areas.

As noted in Jornal Estação de Notícias - Municipios, flooding due to creek overflow is a "historic problem", but its days are numbered, as public works for the Trensurb (a railroad line connecting Novo Hamburgo to Porto Alegre) and the need to canalize the creek will help address this issue (Jornal Estação de Notícias, 2015).

Currently, the creek corresponds to the path of the railway, and its appearance has been completely altered; what little vegetation remained along its banks has been removed to allow containment and lining works, which have turned the stream into a concrete-lined canal. Figure 1 shows remaining vegetation along the creek; its banks were lined with trees and grass, which somewhat mitigated its polluted appearance.

Figure 2 shows the appearance of the Luiz Rau creek after the lining works undertaken to allow railway construction. The creek has become a concrete-lined canal, the purpose of which, according to Trensurb management, is to improve rainwater drainage. All remaining vegetation has been removed to allow the creek bank to be widened, which makes for an image strikingly different from that seen in Figure 2.

Despite these works, this waterway, which once served as a pleasure ground for local residents and as a source of drinking water for animals, now mirrors the lack of care and attention it has received from the authorities and citizens of Novo Hamburgo. The containment and lining works were limited to the span of the creek over which the railway will run, and no measures have been taken to address waste dumping, which continues to this day.

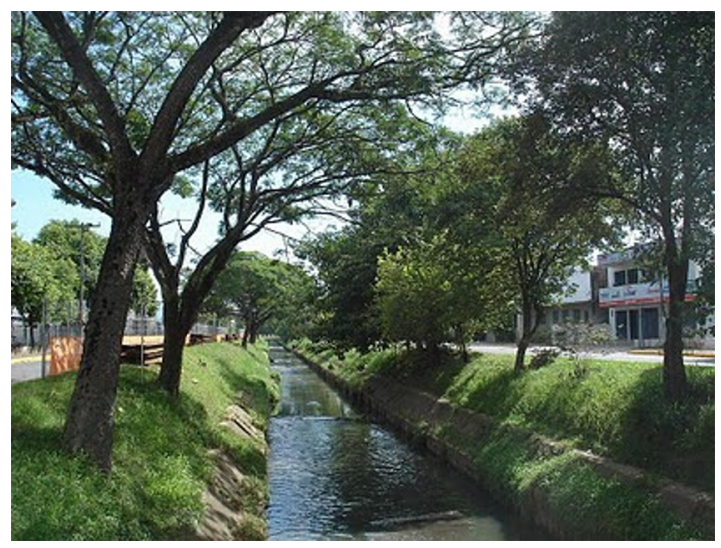

Figure 1. Luiz Rau creek. Source: Cidadão NH (2011).

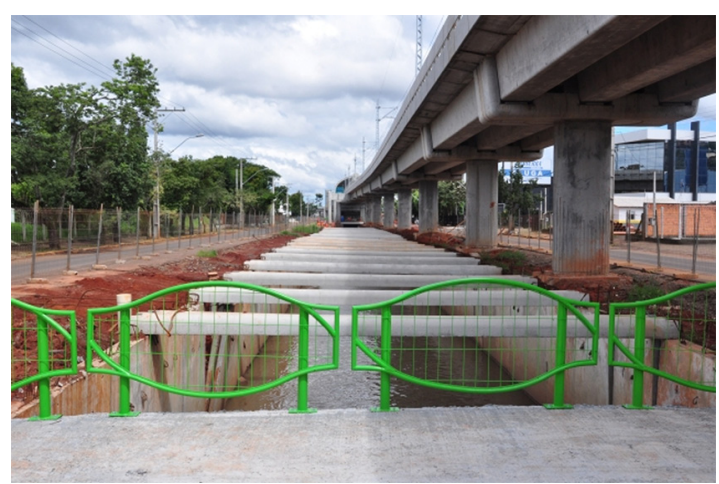

Figure 2. Luiz Rau creek after lining works. Source: Trensurb (2014).

\section{Final Considerations}

The growth and transformation of Novo Hamburgo since its municipal emancipation in 1927 are well known. Industrial progress, supported by the growth of the footwear and leather goods sector, led to the recognition of the city as the Footwear Capital of Brazil in the 1970s. Nonetheless, this achievement was built upon a historical process of changes in the spatiality of Novo Hamburgo. From a humble village, it grew into a major city of the Sinos River Valley region, with a social imaginary based on order and progress as characteristics of its residents, who are "hardworking people", thus supporting the pride of being born - and living - in this German-Brazilian settlement.

Over time, the space of the city was redesigned as a result of urbanization and industrial advancement. From the standpoint of modernity and progress, the spatial organization of Novo Hamburgo was altered as streets were paved, alleys were widened, buildings rose and parking lots were built, among other modifications. Amid this scenario of transformation and as a witness to these changes stood the Vicente Luiz Rau creek, as a landmark, but also as a protagonist of the history of Novo Hamburgo. It gave its banks and the shade of its trees to the local residents that they might organize family gatherings and 
interactions among friends, and thus provided opportunities for socialization.

True, it also served - or rather, was often called on to serve - as an (in)visible border that segregated the central business district from the outskirts of town, but the banks of the creek welcomed one and all. As a monument to local history, it was present for and took part in the historical trajectory of a small village that became a major hub for footwear exports, witnessing such events as the arrival of laborers from other regions of the state of Rio Grande do Sul to fill the tanneries and shoe factories of Novo Hamburgo, as well as the enrichment of many local residents with ties to the footwear industry.

However, it also suffered with an uncaring local population that, otherwise engaged in the daily life of a rapidly progressing city, failed to pay due attention to the pace of urban growth in recent years, which left deep scars in its landscape - and in the population itself. As the 1980s began, the Vicente Luiz Rau creek cried out for help from the residents of Novo Hamburgo, having witnessed the severe consequences of unchecked industrial growth on its waters, which from the very beginning had been used as a dumping ground for municipal waste, as continues to be done even now.

Recent studies conducted by countless researchers also demonstrate that this creek is a research subject, both for its historical condition and for its uses by the local population. This research interest has brought a measure of hope for future improvement of the creek and of the municipality, through monitoring activities designed diagnose its current conditionand, perhaps, through a better use of its waters.

\section{References}

BAUM, D.F.T., 2013 [viewed 27 July 2014]. Esgotamento sanitário na Bacia Hidrográfica do Rio Dos Sinos: uma análise fundamentada na teoria da Sociedade de Risco [online]. Novo Hamburgo: Universidade Feevale, 221 p. Master's Thesis in Environmental Quality. Available from: http://biblioteca.feevale. br/Dissertacao/DissertacaoDanielaBaum.pdf.

BEHREND, M.H., 2002. O 5 de abril. Porto Alegre: Metrópole Indústria Gráfica.

CIDADÃO NH, 2011 [viewed 13 June 2014]. Mostra fotográfica Olhares do Arroio Luiz Rau [online]. Novo Hamburgo: Cidadão NH. Available from: http://cidadaonh.blogspot.com.br/2011/03/ mostra-fotografica-virtual-olhares-do.html.
GERTZ, R., 2002. O aviador e o carroceiro - politica, etnia e religião no RS dos anos 20. Porto Alegre: Edipucrs.

Jornal Estação de Notícias, 2015 [viewed 04 March 2015]. Porto Alegre: Rede Minuano de Comunicação [online]. Available from: https://estacaodenoticias.wordpress.com

Jornal NH, 2 April 1965. Novo Hamburgo: Grupo Sinos.

Jornal NH, 25 November 1981. Novo Hamburgo: Grupo Sinos.

Jornal NH, 23 December 1992. Novo Hamburgo: Grupo Sinos.

Jornal O 5 de Abril, 20 May 1927. Novo Hamburgo: Typographia Hans Behrend.

Jornal O 5 de Abril, 27 February 1931a. Novo Hamburgo: Typographia Hans Behrend.

Jornal O 5 de Abril, 8 July 1931b. Novo Hamburgo: Typographia Hans Behrend.

Jornal O 5 de Abril, 8 April 1932. Novo Hamburgo: Typographia Hans Behrend.

Jornal O 5 de Abril, 26 January 1951. Novo Hamburgo: Typographia Hans Behrend.

MAGALHÃES, M.L., 2010. Entre a preteza e a brancura brilha o Cruzeiro do Sul: associativismo e identidade negra em uma localidade teuto-brasileira (Novo Hamburgo, RS). São Leopoldo: Universidade do Vale do Rio dos Sinos. 219 p. Doctoral Dissertation in History.

PETRY, L., 1944. O município de Novo Hamburgo - Monografia. Porto Alegre: Edições A Nação.

SCHEMES, C., 2006. Pedro Adams Filho: empreendedorismo, indústria calçadista e emancipação de Novo Hamburgo (1901 - 1935). Porto Alegre: Pontifícia Universidade Católica do Rio Grande do Sul. 446 p. Doctoral Dissertation in History.

SELBACH, J., 1999. Novo Hamburgo 1927-1997: os espaços de sociabilidade na gangorra da modernidade. Porto Alegre: Universidade Federal do Rio Grande do Sul. 416 p. Master's Dissertation in History.

TRENSURB, 2014 [viewed 29 June 2014]. Expensão Novo Hamburgo [online]. Porto Alegre: Empresa de Trens Urbanos de Porto Alegre. Available from: http://www.trensurb.gov.br/paginas/ galeria_projetos_detalhes.php?codigo_sitemap $=84$

WEBER, R., 2006. Mosaico identitário: história, identidade e turismo nos municipios da Rota Romântica - RS. Porto Alegre: Universidade Federal do Rio Grande do Sul. 310 p. Master's Thesis in History. 